\title{
Synopsis of the terrestrial vertebrate faunas from the Middle Kura Basin (Eastern Georgia and Western Azerbaijan, South Caucasus)
}

\author{
Maia Bukhsianidze and Kakhaber Koiava \\ Acta Palaeontologica Polonica 63 (3), 2018: 441-461 doi:https://doi.org/10.4202/app.00499.2018
}

This paper summarizes knowledge on the Neogene-Quaternary terrestrial fossil record from the Middle Kura Basin accumulated over a century and aims to its integration into the current research. This fossil evidence is essential in understanding the evolution of the Eurasian biome, since this territory is located at the border of Eastern Mediterranean and Central Asian regions. The general biostratigraphic framework suggests existence of two major intervals of the terrestrial fossil record in the area, spanning ca. 10-7 Ma and ca. 3-1 Ma, and points to an important hiatus between the late Miocene and late Pliocene. General aspects of the paleogeographic history and fossil record suggest that the biogeographic role of the Middle Kura Basin has been changing over geological time from a refugium (Khersonian) to a full-fledged part of the Greco-Iranian province (Meotian-Pontian). The dynamic environmental changes during the Quaternary do not depict this territory as a refugium in its general sense. The greatest value of this fossil record is the potential to understand a detailed history of terrestrial life during demise of late Miocene Hominoidea in Eurasia and early Homo dispersal out of Africa. Late Miocene record of the Middle Kura Basin captures the latest stage of the Eastern Paratethys regression, and among other fossils counts the latest and the easternmost occurence of dryopithecine, Udabnopithecus garedziensis, while the almost uninterrupted fossil record of the late Pliocene-Early Pleistocene covers the time interval of the early human occupation of Caucasus and Eurasia.

Key words: Mammalia, Aves, Reptilia, Miocene, Quaternary, South Caucasus, Kura Basin, Georgia, Azerbaijan.

Maia Bukhsianidze [maiabukh@gmail.com], Georgian National Museum, 3, Purtseladze street, Tbilisi 0105, Georgia. Kakhaber Koiava [koiava_ka@yahoo.com], Ivane Javakhishvili Tbilisi State University, Alexandre Janelidze Institute of Geology, A. Politkovskaia str. 31, Tbilisi 0186, Georgia. 
This is an open-access article distributed under the terms of the Creative Commons

Attribution License (for details please see creativecommons.org), which permits unrestricted use, distribution, and reproduction in any medium, provided the original author and source are credited.

FoF 